\title{
Effect of various Bee wax concentrations on the organoleptic test of sweet orange cv.Valencia late
}

\author{
Kaleemullah ${ }^{*}$, Muhammad Sajid ${ }^{2}$, Zia Ulhaq ${ }^{2}$, Nadir Ali ${ }^{2}$ and Suleman \\ $\mathrm{Jaffar}^{3}$ \\ 1. Department of Horticulture, Faculty of Crop Production Sciences, the University of Agriculture, Peshawar- \\ Pakistan \\ 2. Department of Horticulture, Balochistan Agriculture College, Quetta-Pakistan \\ 3. Department of Soil Science, Balochistan Agriculture College, Quetta-Pakistan \\ *Corresponding author's email:kaleemkakar45@gmail.com
}

Citation

Kaleemullah, Muhammad Sajid, Zia Ulhaq, Nadir Ali and Suleman Jaffar. Effect of various Bee wax concentrations on the organoleptic test of sweet orange cv. Valencia late. Pure and Applied Biology.Vol. 8, Issue 4, pp2295-2301. http://dx.doi.org/10.19045/bspab.2019.80176

\begin{tabular}{llll}
\hline \hline Received: 09/05/2019 & Revised: 15/07/2019 & Accepted: 23/07/2019 & Online First: 03/08/2019 \\
\hline \hline
\end{tabular}

\section{Abstract}

The experiment was carried out to determine the "Effect of bee wax levels on the organoleptic test of sweet orange fruits cv. Valencia late" was conducted at Post Harvest Laboratory, The University of Agriculture Peshawar in 2014. The experiment was Completely Randomized Designed (CRD) with two factors repeated three times. The Bee wax levels (control, 2, 4, 6 and 8\%) were applied to sweet orange fruits, stored at room temperature $\left(16 \pm 1^{\circ} \mathrm{C}\right.$ with relative humidity of $\left.60-70 \%\right)$ for 40 days. After each 10 days of intervals sweet orange fruits were analyzed for different sensory evolution attributes. The highest color score (6.17), aroma score (8.15), taste score (6.85), fruit appearance score (8.33) and texture score (7.14). There was a significant variation in all coated and uncoated fruits with the different storage durations. While minimum color (5.09), aroma (6.28), taste (1.73), appearance (2.80) and texture (1.73) were recorded. Interactive effect of both bee wax and storage intervals had a significant effect on all quality parameters. The maximum fruit color score (5.29), taste score (2.37), aroma score (6.42), fruit appearance score (3.75) and texture score (2.60) was recorded in fruit treated with $8 \%$ bee wax and stored for 40 days. However the minimum fruit color (4.84), taste (1.26), aroma (6.14), appearance (1.81) and texture (1.14) was observed in untreated fruits, respectively. It was concluded that bee wax at $8 \%$ considerably maintained the quality parameters of sweet orange up to 30 days of storage at room condition $\left(16 \pm 1^{\circ} \mathrm{C}\right.$ with relative humidity of $\left.60-70 \%\right)$.

Keywords: Beewax; Oranganoleptic test; Storage duration; Valencia late

\section{Introduction}

Citrus is an important and the largest group of tropical and subtropical fruit. Citrus fruit has been cultivated on wide range since ancient times including oranges, lemon, grape fruit and limes [1]. The fruit is small, orange colored, acidic and juicy with a sweet and edible flesh. Vitamin $\mathrm{C}$ is one of the most important nutritional benefits of citrus fruit. Ascorbic acid (Vitamin C) is the only vitamin present in citrus fruit with major nutritional importance. One orange has $50 \mathrm{mg}$ of vitamin 
$\mathrm{C}$, which is nearly the double of the recommended daily intake and the concentration of ascorbic acid has been reported to decrease with maturity or remain constant until late in the season and then decline [2]. Only $25 \%$ of ascorbic acid in the fruit is in the juice, whereas the remaining is found in the peel, especially in the flavedo [3]. Citrus fruits are used in different ways such as canned, jellies, jams, squashes, juices and ice creams. It is also used as a dessert fruit [4].

Pakistan stands among the top ten citrus growing countries in the world. The citrus fruits are grown over an area of 194.5 thousand hectares with a production of 1912.0 thousand tons per year, while Khyber Pakhtunkhwa contributed the area under citrus is 4.0 thousand hectares with a production of 32.3 thousand tons per year [4]. However, Sargodha, Faisalabad, Sheikhupura and Multan districts of the Punjab province are the major citrus growing areas in the country. During 2003-04, the country exported 85374 thousand tons of citrus fruits worth Rs. 147.5 millions. Kinnow account for $75 \%$ of the total, while oranges constitute 10\% (GOP, 2004).The most compromising qualities of citrus during storage are dehydration caused by loss of moisture from the peel, fruit softening and color degradation [5]. Post-harvest treatments are used to reduce the moisture loss, metabolic activities like respiration and the microorganisms that cause fruits decay [6]. Post-harvest handling operations should be conducted according to the requirement of the commodity to maintain taste, flavor and edibility of fruits [7].

Assortment types of skin coating materials (Bee wax, paraffin wax, carnauba wax, chitosin wax, $\mathrm{CaCl}_{2}$, shellac and $\mathrm{CMC}$ etc.) have been used to restrict moisture loss from the surface of Kinnow, Feutrell's Early and Valencia late cultivars in Pakistan [8]. Coating treatments are known to maintain the quality of stored fruit crops by suppressing moisture loss, improving the strength of peel tissues, retaining volatile components, controlling ripening by modifying $\mathrm{CO}_{2}$ and $\mathrm{O}_{2}$ concentrations inside the fruit [9]. It also acts as a barrier against microbial invasion. However, the ability of the edible film to enhance the shelf life of fruits and vegetables depends on their chemical composition, structure of the film forming polymer, thickness of the coating, formation procedures, various emulsifiers, plasticizers, and storage conditions [10]. An application of wax emulsion helped to maintain visual quality of citrus. Recently, modern carnaubabased wax decreased shell dehydration of 'Golden' pineapple by reducing moisture loss during storage [11].

Keeping in view the importance to increase the post harvest life of sweet orange the proposed study was carried out to evaluate the effect of various bee wax concentrations on the storage life of sweet orange $c v$. "Valencia Late".

\section{Materials and methods}

The experiment "Effect of various bee wax concentrations on the storage life of sweet orange cultivar cv. Valencia Late" was carried out at Post-harvest Laboratory, Department of Horticulture, The University of Agriculture, Peshawar. The sweet orange fruits cv. Valencia Late of about similar size and maturity were collected from Citrus Research Institute (CRI) at Sargodah. The fruits were carefully washed with distilled water before the application of various bee wax concentrations.

Factor $\mathrm{A}=$ Concentrations of bee wax $(0,2$, $4,6$ and $8 \%)$.

Factor B = Storage Durations (0, 10, 20, 30 and 40 days)

\section{Preparation of bee wax solution}

For the preparation of different bee wax solutions, $2 \mathrm{~g}$ of bee wax in $250 \mathrm{ml}$ of conical flask and melted it at $70{ }^{\circ} \mathrm{C}$, heated continuously to attain the temperature 80- 
$90^{\circ} \mathrm{C}$ of melted wax. After that, $0.91 \mathrm{~g}$ stearic acid was then added to the malted wax followed by the addition of $0.55 \mathrm{~g}$ triethanolamine at a constant stirring. The $96.54 \mathrm{ml}$ of distilled water was added slowly and with continued stirring for 5-7 minutes. Prepared emulsion was cooled down at room temperature in tapered vessel [21]. Following the same procedure different emulsion of bee wax (4, 6 and $8 \mathrm{~g})$ has been prepared.

\section{Data collection}

For data analysis three fruits from each treatment were taken for quality parameters and two fruits for sensory evaluation. The data was recorded on freshly harvested fruits and also after every 10 days of durations up to 40 days.

\section{Parameters studied}

In order to study the effect of different bee wax concentrations on the storability of sweet orange following parameters were studied.

1. Taste

2. Texture

3. Aroma

4. Appearance

5. Color

\section{Statistical analysis}

The experiment was laid out in Completely Randomized Design (CRD) with following two factors and repeated three times. The data was statistically analysis to distinction the supremacy of treatment means, using LSD (Least Significant Differences) test, as per the statistical methods developed by [12].

\section{Results and discussion}

\section{Taste}

The calculatedestimations showed that $8 \%$ bee wax had produced appreciably good taste score (4.59), followed by taste score (4.46) recorded in fruits treated with $6 \%$ bee wax. While the minimum taste score (4.06) was recorded in fruits of control treatment. Data regarding storage durations showed that with the increase in storage duration the taste score decreased significantly. The maximum fruit taste score (6.85) was recorded in freshly harvested fruits followed by taste score (5.48) for the fruits stored for 10 days, while the minimum fruit taste score (1.73) was recorded in fruits stored for 40 days.Regarding to their interaction a significant variation was recorded for the fruit taste. The highest taste score (6.86) was recorded in freshly harvested fruits treated with 6 and $8 \%$ bee wax, while the lowest taste score (1.26) was recorded in control fruits stored for 40 days. The application of $8 \%$ bee wax became the reason for the conversion of starches into sugars and hence there was a balance in sugar acid ratio. The fruits that are left without coating did not maintain the ratio of sugar and acid because of the lesser conversion of starches into sugars and it affects the taste of sweet oranges. The deterioration in the taste was due to the anaerobic respiration caused by the micro organisms. The results were also related with the findings of [13], Lewinsohn et al. (2001) reported that taste is mainly affected by sugar acid ratio during storage. The findings of Machado et al. [14] are also related with the present study. According to then the taste edible quality of Jincheng orange was very good without any unpleasant circumstances. Similar results were also reported by Ladaniya et al. [15] who investigated that the taste of Musambi sweet orange (Citrus sinensis) treated with bee wax was good when stored for 30 days.

\section{Texture}

The highest fruit quality texture (4.89) was recorded with $8 \%$ bee wax, followed by texture score (4.71) of sweet orange fruits treated with $6 \%$ bee wax, while the lowest fruit quality texture score (3.95) was noticed in control.The fruit texture extensively decreases with the increase in storage duration. The high quality texture score (7.14) was recorded from the fruits which were freshly harvest, followed by texture 
score (6.35) for the fruits stored for 10 days. While the minimum texture score (1.73) was recorded in fruits stored for 40 days. The interaction of bee wax and storage durations significantly affected the texture score of sweet orange fruits. The maximum texture score (7.15) was recorded in fruits treated with $4 \%$ and $8 \%$ of bee wax respectively. However, minimum texture score (1.14) was recorded in sweet orange fruits of control and stored for 40 days.The pectin enzyme (estarase and poly galacturonidase) present in tissues softens the fruits [16]. [17, 18] Puttalingamma et al. reported that the softening of fruits are also due to the storage temperature during storage. These results are confirmed by [19], they stated that there was an increasedvalue initially and then a regular decrease in the texture of the treated Kinnow fruits during storage.

\section{Aroma}

Bee wax treatment notably influenced the aroma of the sweet orange fruit. However, the mean data shows that the best aroma score (7.37) was recorded in fruits treated with $8 \%$ bee wax followed by aroma score (7.28) in fruits of $6 \%$ bee wax treatment. The lower aroma (7.1) was recorded in untreated fruits. The aroma score of the fruit significantly decreases with the increase in storage duration. The maximum aroma score (8.15) was recorded in fresh fruits which were freshly harvested, followed by aroma score (7.66) in the fruits stored for 10 days, while the minimum aroma score (6.28) recorded in fruits stored for 40 days. A significant variation was recorded for the interaction of bee wax and storage duration regarding aroma score of the fruit. However the maximum aroma score (8.18) was recorded in fresh fruits treated with $8 \%$ bee wax, while the minimum aroma score $(6.14)$ was recorded in untreated fruits stored for 40 days.

The storage duration increases and there is a slight decrease in the aroma of sweet oranges treated with bee wax. Bee wax significantly maintained the aroma of sweet oranges during storage. Same results were also revealed by Porat et al. [20] for apples and Wang et al. [21] for mangoes who stated that the aroma of the fruits maintained with the application of bee wax during storage.

\section{Appearance}

The appearance of the sweet orange is drastically influenced by the treatment of bee wax. Nevertheless, the healthy and good appearance of fruit (6.23) was recorded in fruits treated with $8 \%$ bee wax which is at par with the appearance (6.08) noted in fruits treated with $6 \%$ bee wax. The lowest appearance (5.04) was in untreated fruits during storage. The fruit appearance significantly decreases with the increase in storage duration. The good appearance score (7.36) was noted in fruits, stored for 10 day of durations. As followed by appearance score (6.00) recorded in the fruits stored for 20 days. While the fruit whose appearance score was not an eye catching one was (2.8) recorded in sweet orange fruits stored for 40 days of durations. The interface of bee wax and storage duration of the sweet orange had significantly affected the appearance score of sweet orange fruits during storage. A significant difference was recorded in the appearance of the fruit. The best appearance score (8.35) was recorded in fresh fruits treated with $8 \%$ bee wax while the poor appearance score (1.81) was recorded in untreated fruits stored for 40 days. In view of that, due to some metabolic activities and respiration process sweet oranges reduced the appearance during storage when coated with bee wax. The appearance of fruits decreased with the passage of time during storage duration reported by Bisenet al. [22]. This might be due to the loss of moisture from the surface of the fruit. These results are correlated with the work of Mahajan et al. [23] who observed the same findings in kiwi fruits during storage. 


\section{Color}

The treatment of the bee wax considerably influenced the color of the sweet orange. However the mean data shows that the highest color score (5.79) was recorded in fruits treated with $8 \%$ bee wax, followed by color score (5.74) with $6 \%$ bee wax treatment. The minimum color score (5.50) was found in untreated fruits during storage.The color score of the sweet orange decreases with the increase in storage duration. The best attractive color score (6.17) was noted in sweet orange in fresh fruits followed by color score (5.87) in fruits stored for 10 days. While the poor color score (5.09) was observed in fruits stored for 40 days. A significant variation was recorded for their contact of bee wax and storage duration regarding to the color of the sweet orange. Conversely, the maximum color score (6.18) was recorded in fresh fruits treated with 2 and $6 \%$ bee wax. While the undesirable color score (4.84) was recorded in untreated fruits stored for 40 days. The bee wax coating is the better procedure for keeping the natural color, aroma and taste of sweet oranges. This is because it reduces the respiration rate and also the biochemical activities within the fruits. This leads to the sustainability of all physical properties such as color, appearance, aroma and texture. The results of ouroutput is much similar with the results of $\mathrm{Xu}$ et al. [4] who reported that coating significantly keep the color of Kiwi fruit by reducing the rate of respiration and other biochemical processes (Table No. 1).

Table 1. Effect of Bee wax and storage duration on taste, texture, aroma, appearance and color of sweet orange $\mathrm{cv}$. Valencia late

\begin{tabular}{|c|c|c|c|c|c|}
\hline \multirow{2}{*}{ Beewax (\%) } & \multicolumn{5}{|c|}{ Parameters } \\
\cline { 2 - 6 } & Taste & Texture & Aroma & Appearance & Color \\
\hline 0 & $4.06 \mathrm{e}$ & $3.95 \mathrm{e}$ & $7.12 \mathrm{e}$ & $5.04 \mathrm{e}$ & $5.51 \mathrm{e}$ \\
\hline 2 & $4.15 \mathrm{~d}$ & $4.08 \mathrm{~d}$ & $7.17 \mathrm{~d}$ & $5.43 \mathrm{~d}$ & $5.6 \mathrm{~d}$ \\
\hline 4 & $4.25 \mathrm{c}$ & $4.18 \mathrm{c}$ & $7.23 \mathrm{c}$ & $5.52 \mathrm{c}$ & $5.67 \mathrm{c}$ \\
\hline 6 & $4.46 \mathrm{~b}$ & $4.71 \mathrm{~b}$ & $7.28 \mathrm{~b}$ & $6.08 \mathrm{~b}$ & $5.74 \mathrm{~b}$ \\
\hline 8 & $4.59 \mathrm{a}$ & $4.89 \mathrm{a}$ & $7.37 \mathrm{a}$ & $6.23 \mathrm{a}$ & $5.79 \mathrm{a}$ \\
\hline LSD $(\mathrm{P}<0.05)$ & 0.04 & 0.03 & 0.04 & 0.05 & 0.05 \\
\hline \multicolumn{7}{|c|}{ Storage durations (days) } \\
\hline Fresh & $6.85 \mathrm{a}$ & $7.14 \mathrm{a}$ & $8.15 \mathrm{a}$ & $8.33 \mathrm{a}$ & $6.17 \mathrm{a}$ \\
\hline 10 & $5.48 \mathrm{~b}$ & $6.35 \mathrm{~b}$ & $7.66 \mathrm{~b}$ & $7.36 \mathrm{~b}$ & $5.87 \mathrm{~b}$ \\
\hline 20 & $4.41 \mathrm{c}$ & $3.18 \mathrm{c}$ & $7.31 \mathrm{c}$ & $6.22 \mathrm{c}$ & $5.67 \mathrm{c}$ \\
\hline 30 & $3.06 \mathrm{~d}$ & $2.78 \mathrm{~d}$ & $6.75 \mathrm{~d}$ & $3.81 \mathrm{~d}$ & $5.49 \mathrm{~d}$ \\
\hline 40 & $1.73 \mathrm{e}$ & $1.73 \mathrm{e}$ & $6.28 \mathrm{e}$ & $2.81 \mathrm{e}$ & $5.09 \mathrm{e}$ \\
\hline LSD $(\mathrm{P}<0.05)$ & 0.08 & 0.07 & 0.090 & 0.11 & 0.07 \\
\hline
\end{tabular}

\section{Conclusion and recommendations}

Results showed that Bee Wax effectively helped in maintaining the sensory evolution of sweet orange by sustaining aroma, appearance, color, taste and texture.Bee Wax application at $8 \%$ was efficient to control the taste texture and aroma and color while for appearance $2 \%$ bee wax was efficient .With regards to storage interval the fruits maintained its quality upto 30 days at room condition $\left(16 \pm 1^{0} \mathrm{C}\right.$ with relative humidity of $60-70 \%$ ) without deteriorating its quality attributes. 


\section{Authors' contributions}

Conceived and designed the experiments: $\mathrm{N}$ Ali \& S Jaffar, Performed the experiments: Kaleemullah, Analyzed the data: M Sajid, Contributed materials/ analysis/ tools: Z Ulhaq, N Ali \& S Jaffar, Wrote the paper: Kaleemullah.

\section{References}

1. Aguilar GA, Rodriguez JAV, Zavala JFA \& Yahia EM (2010). Improvement of the antioxidant status of tropical fruits as a secondary response to some postharvest treatments. Trends Food Sci Technol 21: 475-482.

2. Faheem UH, Muhammad S, Muhammad NK, Imran HK, Syed TS \& Dawood (2018). Influence of salicylic acid and storage durations on sensory evaluation of sweet orange cv. blood red. Pure Appl Biol 7(4): 1197-1202.

3. Alam MS \& Paul S (2001). Effect of cellulose based edible coating on shelf life of kinnow. J Res Punjab Agric Univ 38(1-2): 76-81.

4. Xu Q, Chen LL, Ruan X, Chen D, Zhu A, Chen C, Bertrand D, Jiao WB, Hao $\mathrm{BH}$, Lyon MP, Chen J, Gao S, Xing F, Lan H, Chang JW, Ge X, Lei Y, Hu Q, Miao Y, Wang L, Xiao S, Biswas MK, Zeng W, Guo F, Cao H, Yang X, Xu XW, Cheng YJ, Xu J, Liu JH, Luo OJ, Tang Z, Guo WW, Kuang H, Zhang HY, Roose ML, Nagarajan N, Deng XX \& Ruan Y ( 2013). "The draft genome of sweet orange (Citrus sinensis)". Nature Genetics 45: 59-66.

5. Kirsten D, Peggy MT \& Phoebe Q (2009). Edible Films and Coatings for Food Applications; Structure and Function of Protein-Based Edible Films and Coatings, ISBN 978-0-387-928234; pp 25-56.

6. Mehrdad J \& Sajad F (2012). Post harvest treatments on shelf life of sweet orange "Valencia". J Med Plants Res 6(11): 2117-2124.
7. Fattahi J, Fifairand Babri M (2010). Post-harvest quality of kiwifruit (Actinidia deliciosa cv.) affected by prestorage application of salicylic acid. $S W$ $J$ of Hort Bioland Environ (2): 175-186.

8. Hayat I, Tmasud \& Rathore HA (2005). Effect of coating and wrapping materials on the shelf life of apple (Malus domestic acv. Borkh). Int J Food Saf 9(5): 24-34.

9. AlemzadehAN \& Feridon H (2007). Postharvest application of hot water, fungicide and waxing on the shelf life of valencia and local oranges of siavarz. Asi J Plant Sci 6: 314-319.

10. Khosroshahi ZRM, Ashari EM \& Ershadi A (2007). Effect of exogenous putrescine on post-harvest life of strawberry (Fragari aananassa Duch.) fruit cultivar Selva. Scientia Horti 114: 27-32.

11. Ladaniya MS (2001). Response of 'Musambi' sweet orange (Citrus sinensis) to degreening, mechanical waxing, packaging and ambient storage conditions. Ind J Agric Sci 71(4): 234 239.

12. Jan MT, Shah P, Hollington PA, Khan MJ \& Shohail Q (2009). Agriculture Research: Design and Analysis. $1^{s t} e d$ Dept Agro KPK Agric Uni Peshawar Pak 34-38.

13. Lewinsohn E, Schalechet S, Wilkinson J, Matsui K, Tadmor Y, Nam K, Amar O, Lastochkin E, Larkov O, Ravid U, Hiatt W, Gepstein S \& Pichersky E (2001). Enhanced level of aroma and flavour compounds S-lonalole by metabolic engineering of terpeniod pathway in tomato fruits. $P$ Physiol 27: 1256-1265.

14. Machado FL, Costa CJMC \& Batista EN (2012). Application of carnauba-based wax maintains postharvest quality of 'Ortanique' tangor. Ciênc Tecnol Aliment Campinas 32(2): 261-266.

15. Abad I \& Martinez JM (2002). Influence of storage 
temperature and waxing on the keeping quality of caraca oranges: Improving postharvest technologies of fruit, vegetable and ornamental. IIR Conf 1: 226-230.

16. Meena RK \& Yadav JS (2001). Horticulture marketing and post harvest management. Pionter PublInd, pp 39.

17. MINFA (2010-11). Government of Pakistan Statistics Division Pakistan Bureau Statistics. 44: 9-89.

18. Puttalingamma V \& Begum K (2009). Biocoating of Carrot and Beans for their shelf life. Int J of Food Sci and Nut 3(2): 31-40.

19. Abdelaziz FH \& Ahmed FF (2000). Effect of citrus rootstock and waxing on shelf-life and quality of Valencia orange fruit: Improving postharvest technologies of fruit, vegetable and ornamental. IIR Conf 1 : 127-131.
20. Porat R, Weiss B, Cohen L, Daus A \& Biton A (2005). Effects of polyethylene wax content and composition on taste, quality and emission of off-flavor volatiles in Mor mandarins. Postharv Biol Technol 38: 262-268.

21. Wang RK, Shao P, Zhou L \& Zhu RG (2004).Effect of fruit waxing Agent A on the commodity quality of Jincheng orange variety. South China Fruits 4: 1314.

22. Bisen A \& Pandey SK (2008). Effect of post harvest treatments on biochemical and organoleptic constitutes of Kagzi lime fruits during storage. J Hortic Sci 3: 53-56.

23. Mahajan BVC, Bhatt AS \& Sandhu KS (2005). Effect of different post harvest treatment on the storage life of kinnow. $J$ Food Sci Technol 42: 296-299. 